\title{
ESA weighs up future after Ariane explosion
}

David Adam, London

It was intended to be a show of strength, but after the spectacular failure of the new 'heavy-lifter' Ariane rocket, the only thing hoisted into space by the European Space Agency (ESA) last week was a weighty doubt over its future in the launch business.

Faced with a grim record of 4 failures from just 14 Ariane 5 launches, some observers were starting to ask if Europe's 25year-old rocket programme is more trouble than it's worth. But most space scientists appear confident that ESA can ride out the latest failure and go ahead with launches of most of its planned scientific satellites.

An investigation is already under way into what caused the souped-up E150million (US\$150-million) Ariane 5 ECA to veer dangerously off course and self-destruct just three minutes into its maiden flight from Kourou, French Guiana, on 11 December. One of the investigation's first tasks is to determine whether the fault has any bearing on the classic Ariane 5 design - which is supposed to take the Rosetta satellite mission on the first leg of its journey to rendezvous with a comet in just a few weeks' time.

"We have to understand what happened first, but it's most probable that Rosetta will launch on schedule on 12 January," Jean-Yves Le Gall, director of the ill-fated mission, told reporters at a press conference in Kourou.

The spacecraft is intended to rendezvous with the comet Wirtanen in 2011, when it will place one probe in orbit and land another on the nucleus (see Nature 417, 889; 2002). The mission aims to observe the comet as it heats up on its approach to the Sun and begins to spew out gas and dust. But if it is to keep its appointment it must be launched before the end of next month.

The rocket's loss is a heavy blow for both ESA and Arianespace, the company it set up to develop and operate the launchers. Each is banking on Ariane 5 ECA's success to win contracts to launch commercial satellites.

"This really couldn't have come at a worse time for Ariane," says Patrick French, an analyst with consultants Frost and Sullivan in Mountain View, California, who specializes in the satellite industry. The market in commercial satellite launching is depressed because of the slump in the telecommunications industry, French points out. With no military and government contracts, delays could force ESA to request extra cash from its member states to keep the Ariane programme afloat.

The money will probably be found, French says: "Europe is not going to abandon Ariane because it will still want independent access to space."

David Southwood, ESA's director of science, insists that the European space industry will "rise again" and still has a bright future. "You don't get into this business

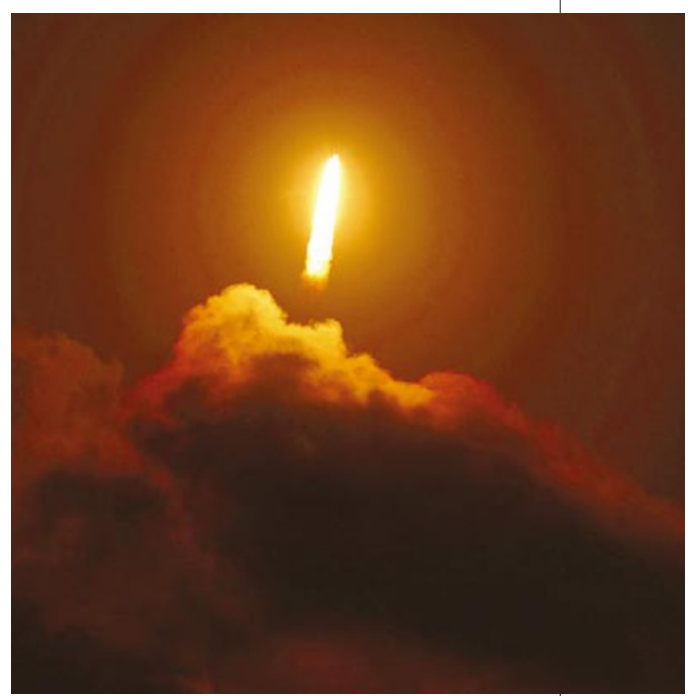

Dark skies: Europe's Ariane 5 ECA 'heavy lifter' blew up just three minutes after launch.

without realizing that failures happen," he says. "It's a setback in the short term, but I don't doubt that a launcher of that capability will emerge."

Although developed primarily for the commercial market, a new class of heavylifter rockets will also be used to launch the next generation of deep-space research probes, such as the planned James Webb space telescope, Southwood says.

\section{Australian bushfire centre rises from the flames}

\section{Carina Dennis, Sydney}

With bushfires raging around Sydney for the second consecutive summer, Australia is turning to science for guidance on land and fire management. On 10 December, science minister Peter McGauran announced that A $\$ 25$ million (US\$14 million) will be spent on a multisite centre devoted to the study of bushfires.

The Bushfire Cooperative Research Centre (CRC) will commence work next July, and will involve participants from several universities, fire and emergency services, national parks and landmanagement groups.

Announced as part of a package of 12 new centres of this type, the bushfire initiative will be funded initially for seven years with the federal money and a further A\$87 million allocated over that period by its various participants.

"The centre will have a focus on reducing risk to life and property," says Leon Collett, programme coordinator of the Australasian Fire Authorities Council, a representative body for fire and emergency services and land-management agencies that led the bid for the centre.

The CRC will have its headquarters in Melbourne, but the research will be carried out across the sites of the participating groups. "The history of bushfire research in Australia has been too small, unfocused and not well integrated. What the CRC does is assemble a critical mass for scientists working on a broad set of problems," says Collett.

The centre will investigate fire behaviour and ecology, smoke hazards, building design and construction materials, and will develop education programmes for the public. It will also investigate the impact of prescribed burning - the contentious practice of lighting controlled fires to remove hazardous build-ups of vegetation.

But some researchers have expressed disappointment at the centre's emphasis on fire management near urban areas an issue of pressing relevance to
Australia's heavily populated southeastern states. They point out that most bushfires actually occur in the less-populated northern reaches of the continent. "We would have preferred a more national approach to bushfire research," says Jeremy Russell-Smith, a fire-management consultant at the Bushfires Council of the Northern Territory.

This was the third attempt by various parties to set up a bushfire research centre. The success was due to having "the right mix" of participants, says Rodney Weber, a mathematician at a campus of the University of New South Wales in Canberra who plans to model bushfire ecology for the CRC.

This year's fires have already wreaked significant destruction around Sydney, with about 730,000 hectares burned in New South Wales so far, signalling another season of damage and uncertainty around Australia's largest city. The fires are being exacerbated by searing temperatures, strong winds and drought conditions. 